\title{
Author Correction: Long non-coding RNA NR2F1- AS1 induces breast cancer lung metastatic dormancy by regulating NR2F1 and $\Delta \mathrm{Np} 63$
}

Yingjie Liu, Peiyuan Zhang, Qiuyao Wu, Houqin Fang, Yuan Wang, Yansen Xiao, Min Cong, Tingting Wang, Yunfei He, Chengxin Ma, Pu Tian, Yajun Liang, Lun-Xiu Qin, Qingcheng Yang, Qifeng Yang (D, Lujian Liao \& Guohong Hu (1)

Correction to: Nature Communications https://doi.org/10.1038/s41467-021-25552-0, published online 02 September 2021.

This Article contained an error in the Acknowledgments section. In the Acknowledgements section the author omitted to include a grant from the Ministry of Science and Technology of China, 2020YFA0112302, for which the work received financial support.

This error has been corrected in the HTML and PDF versions of the Article.

Published online: 07 October 2021

\footnotetext{
(c) Open Access This article is licensed under a Creative Commons Attribution 4.0 International License, which permits use, sharing, adaptation, distribution and reproduction in any medium or format, as long as you give appropriate credit to the original author(s) and the source, provide a link to the Creative Commons license, and indicate if changes were made. The images or other third party material in this article are included in the article's Creative Commons license, unless indicated otherwise in a credit line to the material. If material is not included in the article's Creative Commons license and your intended use is not permitted by statutory regulation or exceeds the permitted use, you will need to obtain permission directly from the copyright holder. To view a copy of this license, visit http://creativecommons.org/licenses/by/4.0/.
}

(C) The Author(s) 2021 